\title{
THE EFFECTIVENESS OF INFORMATION SERVICE IN IMPROVING STUDENTS' SELF CONTROL AGAINST SEXUAL HARASSMENT IN VOCATIONAL SCHOOL IN PADANG
}

\author{
Firman Firman, Herman Nirwana and Syahniar Syahniar, Universitas Negeri Padang \\ E-mail : firman@konselor.org
}

\begin{abstract}
Information service as one type of guidance and counseling services in schools has lost its function in helping students to control themselves from performing sexual harassment. This research aims to determine the effectiveness of information service in improving students' self control against sexual harassment. This is a quantitative research with an experimental design. The research population is students of a Vocational School in Padang and the sampling technique is cluster random sampling. Data collection was performed through a questionnaire on self-control and data were analyzed using $\mathrm{t}$ test. The results of the test reveal that information service is effective in improving students' self control against sexual harassment, with the help of Guidance and Counseling teachers/ the school's Counselor to prevent sexual harassment in schools.
\end{abstract}

Keyword: Information service, Self-Control, Sexual Harassment

\section{PENDAHULUAN}

Kejahatan seksual di Indonesia dari tahun ke tahun meningkat. Komisi Nasional Perlindungan Anak (KPAI) (2014) menemukan sebanyak 42-58\% dari pelanggaran yang ada di negara ini merupakan kejahatan seksual. Salah satu kejahatan seksual yang terjadi yaitu pelecehan seksual (Komnas Perempuan, 2015). Sebagian besar korban pelecehan seksual, yaitu anak dan remaja perempuan yang pelakunya berasal dari latar belakang berbeda, baik dari segi usia, pendidikan, pekerjaan, status sosial ekonomi dan tempat tinggal. Pelaku pelecehan seksual tidak mengenal perbedaan status, pangkat, jabatan dan sebagainya (Syaiful Bahri \&Fajriati, 2015).

Pelecehan seksual merupakan segala bentuk perilaku bersifat seksual yang tidak diinginkan oleh korban yang mendapat perlakuan tersebut.Pelecehan seksual dapat dialami oleh semua perempuan (Collier, 1992). Bentuk tindakan pelecehan seksual, diantaranya : menjahili perempuan di jalanan, menceritakan lelucon kotor yang merendahkan derajatnya hingga tindakan tidak senonoh dan pemerkosaan.

Dampak psikologis pelecehan seksual kepada korban, yaitu: (1) jengkel, senewen, marah, stress hingga breakdown, (2) ketakutan, frustasi, rasa tidak berdaya dan menarik diri, (3) kehilangan rasa percaya diri, (4) merasa berdosa atau merasa dirinya sebagai penyebab, (5) kebencian yang digeneralisasi kepada jenis kelamin yang sama dengan pelaku (Kelly,1998). Perempuan yang mengalami pelecehan seksual berakibat kepada fisik, seperti gangguan pencernaan, nyeri tulang belakang, gangguan makan, gangguan tidur dan mudah marah. Sedangkan akibat psikologis yang dirasakan, antara lain: perasaan terhina, terancam dan tidak berdaya (Rumini \&Sundari ,2004). 
Pelecehan seksual di lingkungan remaja siswa sekolah menengah berkaitan dengan perkembangan psikologis yang sedang dijalaninya.Masa remaja merupakan peralihan dari anak-anak menuju dewasa yang ditandai dengan perubahan biologis, psikologis dan sosiologis.Faktor lingkungan memberikan pengaruh terhadap pembentukan perilaku seksual remaja. Individu yang memiliki kontrol diri rendah mengalami kesulitan mengatur dan mengarahkan perilakunya, sehingga akan berperilaku menyenangkan dirinya, termasuk menyalurkan hasrat seksualnya baik dalam bentuk berpacaran ataupun pelacuran (Yuniar, Dika, \& Anggela, 2013).

Dorongan yang muncul pada remaja akan membentuk perilaku seksual dengan nilai-nilai yang dimilikinya. Nilai-nilai diperoleh melalui informasi dari lingkungan, baik sekolah, teman, keluarga dan masyarakat (Kusmiran, 2011). Remaja yang tidak mempunyai pengetahuan tentang perilaku seksual akan menjadi salah satu penyebab terjadinya pelecehan seksual (Fuadi, 2011).

Greenbeerg menjelaskan remaja mendapatkan informasi mengenai seks diklasifikasikan sebanyak $21 \%$ diperoleh dari rumah, $15 \%$ dari sekolah, $28 \%$ dari media massa dan film serta $40 \%$ teman sebaya. Remaja berasal siswa sekolah menengah melakukan pelecehan seksual sebanyak 27,37 $\%$. Pelecehan seksual yang terbanyak dilakukan remaja yaitu pelecehan seksual verbal sebanyak $66,66 \%$, visual sebanyak 62,69 \% dan fisik sebanyak 44,83\% (Firman,.Syahniar. 2015).

Guru BK/Konselor mempunyai tanggungjawab untuk mencegah remaja dari pelecehan seksual, baik menjadi korban ataupun pelaku. Salah satu cara mencegah terjadinya pelecehan seksual, yaitu memberikan pemahaman dan pengetahuan tentang sikap positif seksualitas melalui layanan informasi. Firman \& Syahniar (2017) menemukan layanan informasi yang diperlukan remaja di sekolah yang dirumuskan dari perencanaan, pelaksanaan, evaluasi dan tindak lanjut. Topik pembahasan yang digunakan, menyangkut dengan: pelecehan seksual beserta akibatnya, aturan-aturan berkaitan dengan pelecehan seksual beserta dampak pelanggarannya, dan toleransi antar jenis kelamin dalam mengimplimentasikan aturan berkaitan dengan pelecehan seksual.

Layanan informasi bertujuan membekali individu dengan berbagai macam pengetahuan tentang lingkungan yang diperlukan dalam memecahkan masalah yang dihadapinya. Bertitik tolak dari uraian tersebut, melalui tulisan ini menarik dikaji lebih lanjut bagaimana pencegahan kejahatan seksual melalui layanan informasi untuk meningkatkan kontrol diri remaja siswa SMK. Pengungkapan permasalahan tersebut berguna untuk menemukan solusi dalam pencegahan kejahatan seksual di kalangan remaja siswa sekolah menengah.

\section{METODE PENELITIAN}

Penelitian menggunakan metode kuantitatif dengan pendekatan eksperimen. Populasi penelitian siswa SMK Kota Padang dan pengambilan sampel menggunakan cluster random sampling. Data dikumpulkan melalui kuessioner kontrol diri Firman dan Yenikarneli (2017) dan kuessioner pelecehan seksual Firman, Syahniar \& Anajmi (2017). Validitas dan reliabilitas 
kuesioner diuji dengan rasch model. Berdasarkan pengujian ditemukan instrumen kontrol diri dan pelecehan seksual valid dan reliabel.

Penelitian dilaksanakan di Sekolah Menengah Kejuruan (SMK) Kota Padang, dengan populasi penelitian sebanyak 11.709, terdiri atas siswa sekolah negeri dan swasta. Sampel diambil menggunakan cluster random sampling dan data dianalisis dengan persentase dan uji " $t$ " untuk melihat perbedaan kontrol diri remaja siswa SMP setelah mengikuti layanan informasi.

\section{HASIL PENELITIAN DAN PEMBAHASAN}

\section{Hasil Penelitian}

Berdasarkan hasil penelitian ditemukan hal sebagai berikut :

\section{Kontrol Diri Remaja Siswa SMK Kelompok Eksperimen dalam Mengikuti Layanan Informasi.}

Setelah diberikan layanan informasi kepada kelompok eksperimen ditemukan kontrol diri remaja siswa SMK, sebagai berikut :

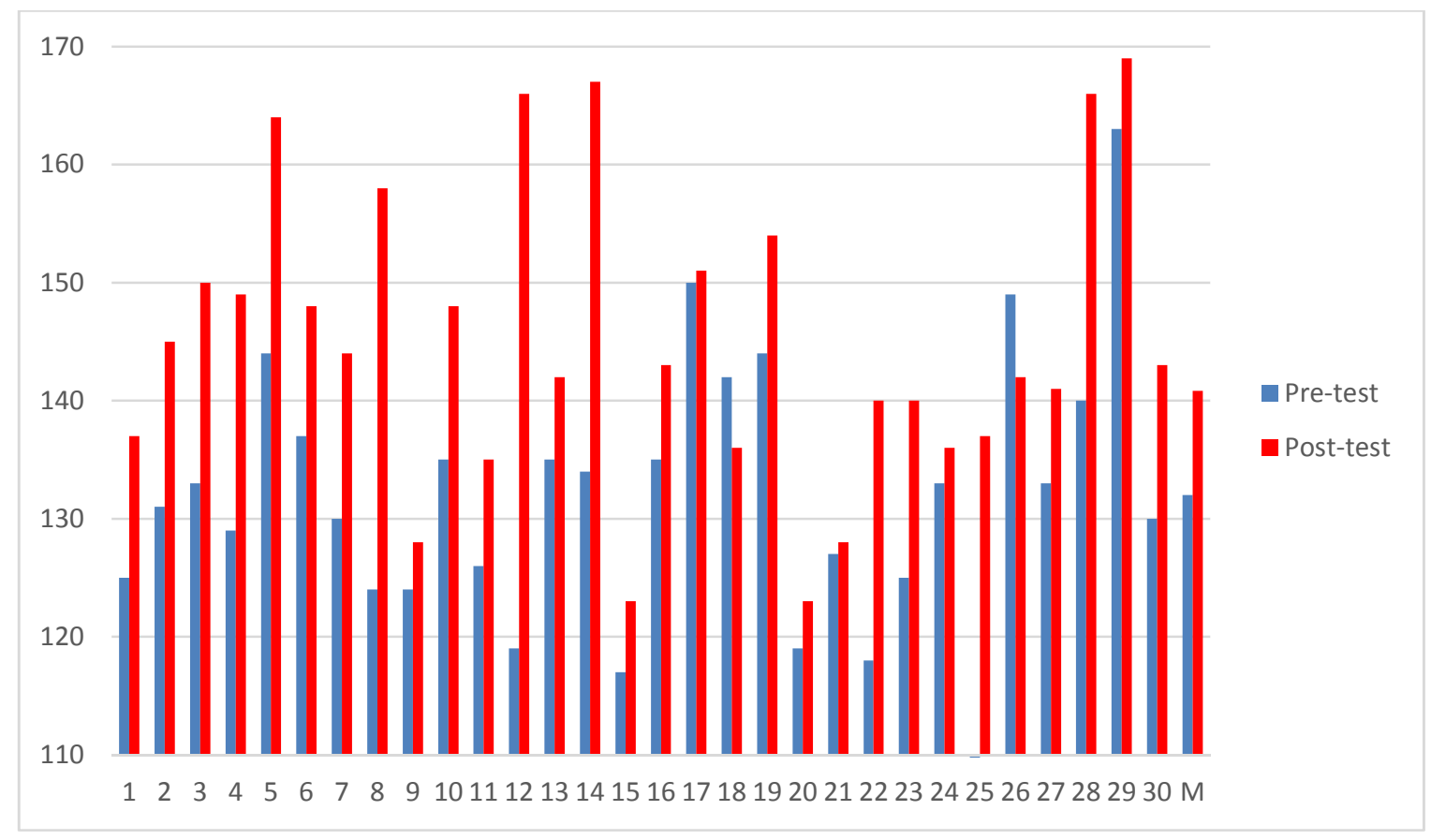

\section{Diagram 1 : Kontrol Diri Remaja Siswa SMK Kelompok Eksperimen Mengikuti Layanan Informasi}

Berdasarkan tabel di atas, ditemukan kontrol diri remaja siswa SMK kelompok eksperimen mengalami peningkatan setelah mengikuti layanan informasi, Sebelum mengikuti layanan informasi rata-rata skor pretest sebesar 132 dan berada pada kategori cukup baik. Selanjutnya, setelah mengikuti layanan informasi rata-rata skor posttest meningkat menjadi sebesar 140.83 dan berada pada kategori baik.

Perbedaan frekuensi kontrol diri siswa kelompok eksperimen setelah dilakukan pretest dibandingkan posttest menunjukan sebagai berikut ini. 


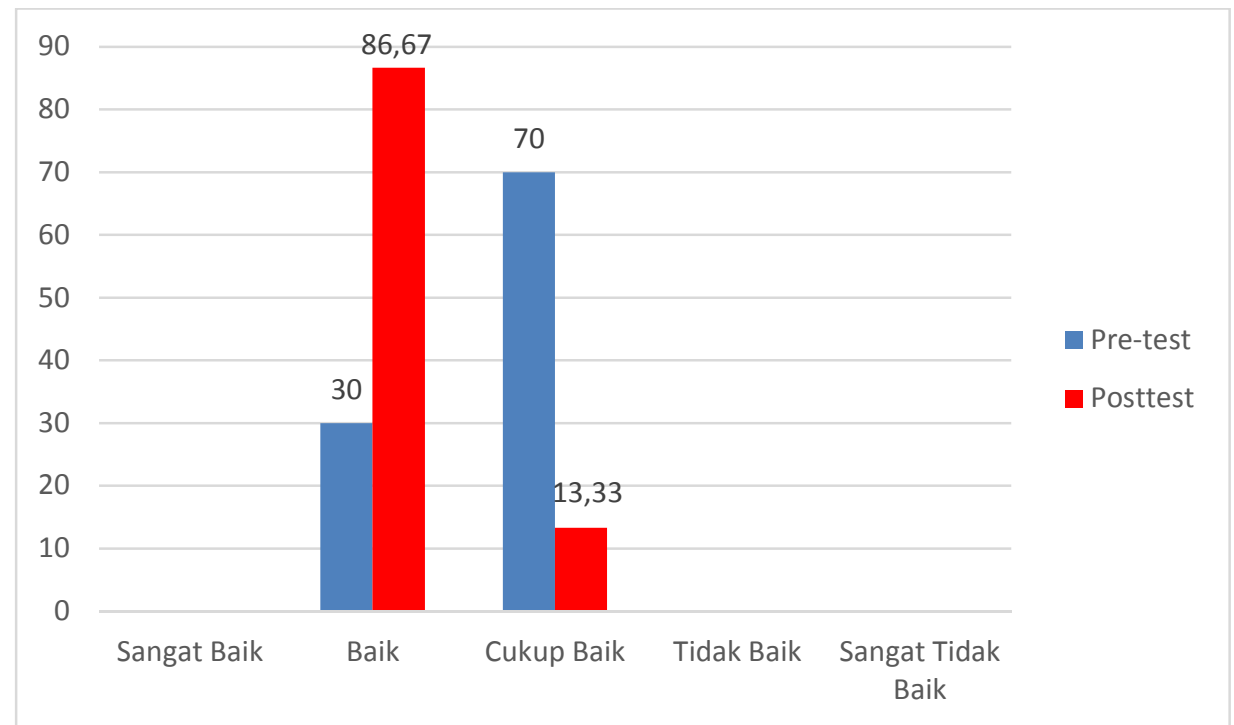

\section{Diagram 2 : Kontrol Diri Remaja Siswa SMK Kelompok Eksperimen Melakukan Pelecehan Seksual Sebelum dan Setelah Mengikuti Layanan Informasi}

Berdasarkan Tabel di atas, ditemukan terdapat perbedaan kontrol diri siswa SMK melakukan pelecehan seksual pada kelompok eksperimen sebelum dan sesudah mengikuti layanan informasi. Setelah pretest dilakukan ditemukan sebanyak 9 orang berada pada kategori baik dengan persentase sebesar 30\% dan 21 orang siswa berada pada kategori cukup baik dengan persentase sebesar 70\%. Setelah mengikuti layanan informasi, dilakukan posttest ditemukan perubahan, sebanyak 26 orang siswa berada dalam kategori baik dengan persentase sebesar $86.67 \%$, dan 4 orang siswa berada dalam kategori cukup baik dengan persentase sebesar $13.33 \%$. \%.

Setelah dilakukan pengujian hipotesis, hasil perhitungan ditemukan Sig.(2-tailed) lebih kecil dari taraf signifikansi $0.05(0.000<0.05)$. Hal ini menunjukan terdapat perbedaan yang signifikan kontrol diri remaja siswa SMK melakukan pelecehan seksual kelompok eksperimen sebelum dan sesudah mengikuti layanan informasi.

\section{Kontrol Diri Siswa Kelompok Kontrol Sebelum dan Setelah Mengikuti Layanan informasi dengan Kegiatan Konvensional dalam Pencegahan Pelecehan Seksual.}

Berdasarkan hasil penelitian terhadap kelompok kontrol yang mengikuti layanan informasi secara konvensional, ditemukan sebagai berikut : 


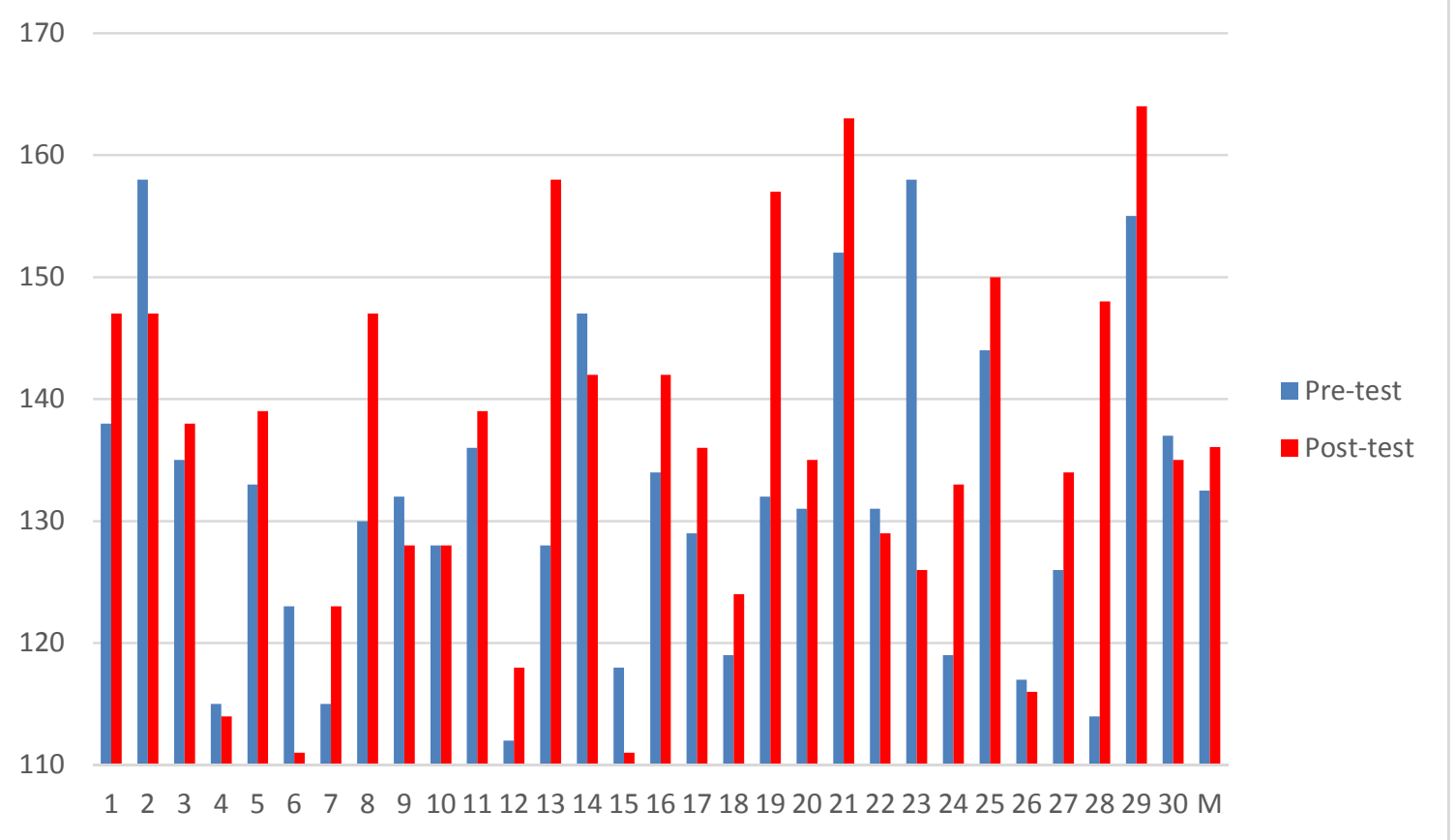

\section{Diagram 3 : Kontrol Diri Remaja Siswa SMK Kelompok Kontrol Setelah Mengikuti Layanan Informasi Secara Konvensional}

Berdasarkan Tabel di atas, ditemukan kontrol diri remaja siswa SMK kelompok kontrol setelah mengikuti layanan informasi secara konvensional mengalami peningkatan walaupun dalam katagori yang sama. Sebelum mengikuti layanan informasi, ditemukan rata-rata skor pretest sebesar 132.5 dan berada pada kategori cukup baik. Setelah mengikuti layanan informasi secara konvensional rata-rata skor posttest meningkat menjadi sebesar 136.06 dan berada pada kategori cukup baik.

Perbedaan frekuensi kontrol diri remaja siswa SMK kelompok kontrol setelah dilakukan pretest dibandingkan dengan posttest terlihat sebagai berikut :

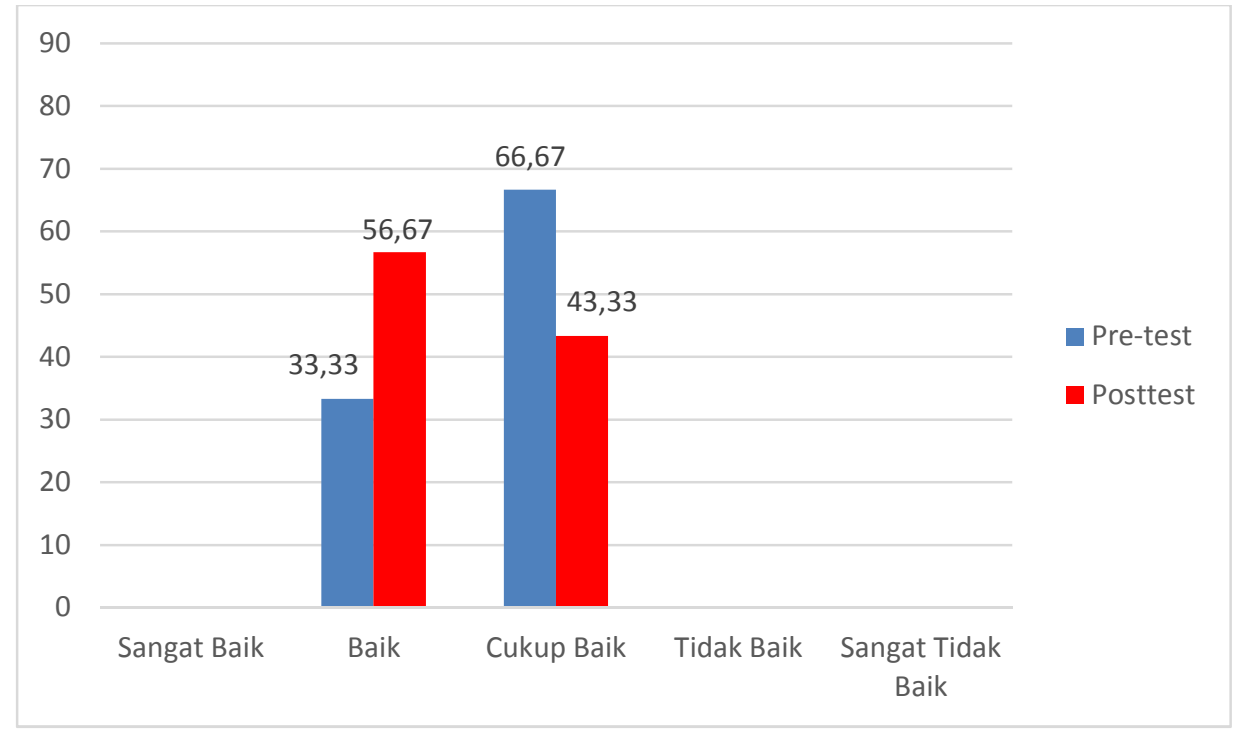

Diagram.4 : Frekuensi Kontrol Diri Remaja Siswa SMK Sebelum dan Setelah Mengikuti Layanan Informasi Secara Konvensional 
Berdasarkan Tabel di atas, ditemukan perbedaan kontrol diri remaja siswa SMK kelompok kontrol melakukan pelecehan seksual sebelum dengan sesudah mengikuti layanan informasi. Setelah pretest ditemukan kontrol diri 10 orang siswa melakukan pelecehan sesksual berada pada kategori baik dengan persentase sebesar $33.33 \%$ dan 20 orang siswa berada pada kategori cukup baik dengan persentase sebesar $66.67 \%$. Setelah mengikuti layanan informasi ditemukan perubahan yang ditunjukan berdasarkan hasil posttest, sebanyak 17 orang siswa berada dalam kategori baik dengan persentase sebesar $56.67 \%$, dan 13 orang siswa berada dalam kategori cukup baik dengan persentase sebesar $43.33 \%$. Setelah dilakukan pengujian hipoteisi ditemukan Sig.(2-tailed) lebih besar dari taraf signifikansi $0.05(0.213>0.05)$. Hal ini menunjukan terdapat perbedaan yang signifikan kontrol diri remaja siswa SMK melakukan pelecehan seksual kelompok kontrol setelah mengikuti layanan informasi secara konvensional.

\section{Perbedaan Kontrol Diri Remaja Siswa SMK Kelompok Kontrol dengan Kelompok Eksperiman setelah Mengikuti Layanan Informasi.}

Perbedaan kontrol diri remaja siswa SMK melakukan pelecehan seksual kelompok eksperimen dibandingkan dengan kelompok kontrol setelah kegiatan layanan informasi, ditemukan sebagai berikut :

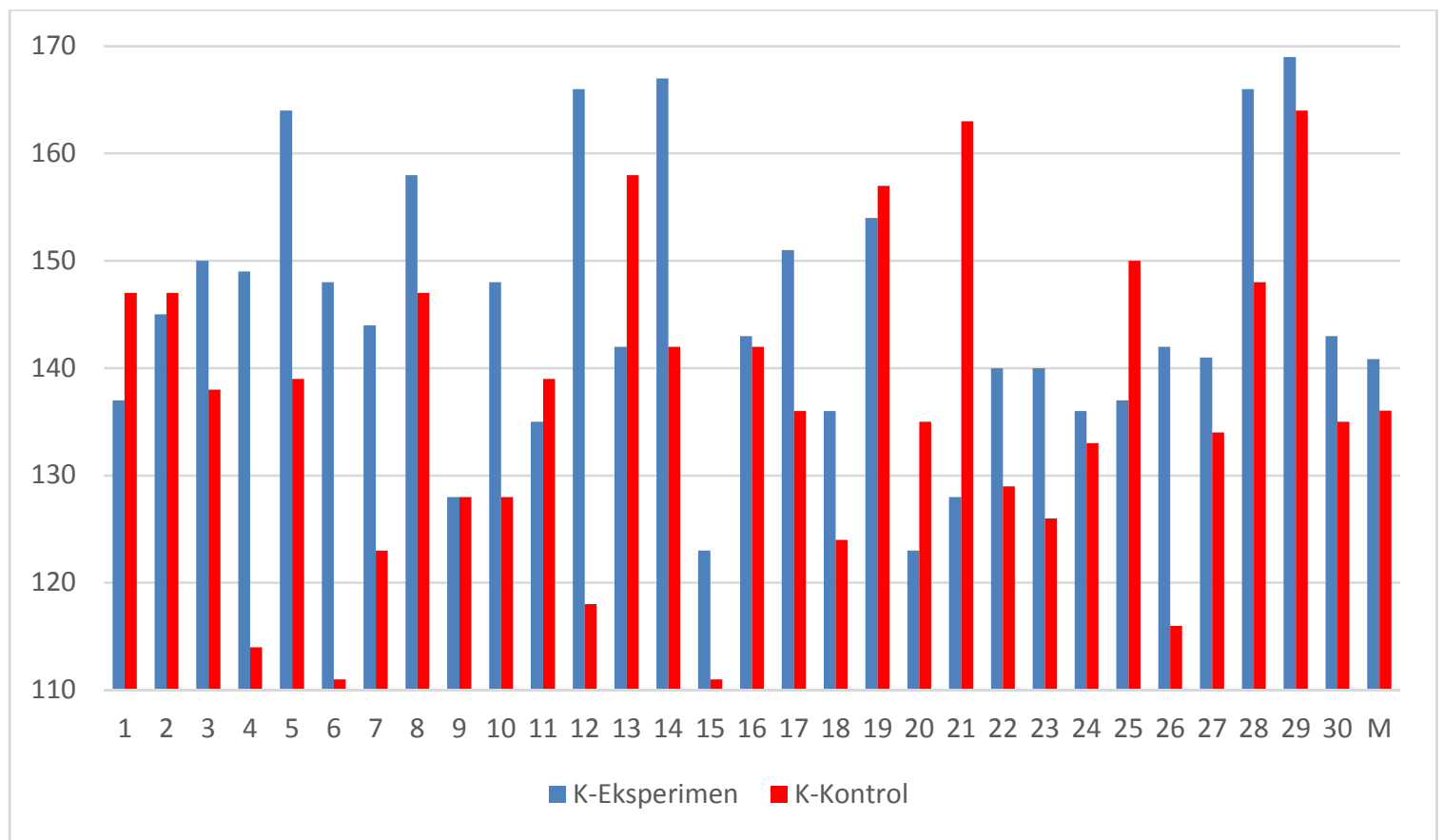

\section{Diagram 5 : Kontrol Diri Remaja Siswa SMK terhadap Pelecehan Seksual Kelompok Eksperimen dan Kelompok Kontrol}

Berdasarkan diagram di atas, ditemukan kontrol diri kelompok ekperimen ditunjukan oleh 26 orang siswa berada pada kategori baik, sebanyak 4 orang memiliki kontrol diri cukup baik. Rata-rata 
skor posttest kontrol diri siswa kelompok eksperimen sebesar 140.83 yang berada pada kategori baik. Selanjutnya, kelompok control memiliki kontrol diri kategori baik berjumlah 17 orang dan kontrol diri siswa berada pada kategori cukup baik berjumlah 13 orang. Rata-rata skor posttest kontrol diri siswa pada kelompok kontrol sebesar 136.06 yang berada pada kategori cukup baik. Sig.(2-tailed) lebih kecil dari taraf signifikansi $0.05(0.014<0.05)$. Hal ini menunjukan terdapat perbedaan kontrol diri melakukan pelecehan seksual kelompok eksperimen dibandingkan kelompok kontrol setelah mengikuti layanan informasi.

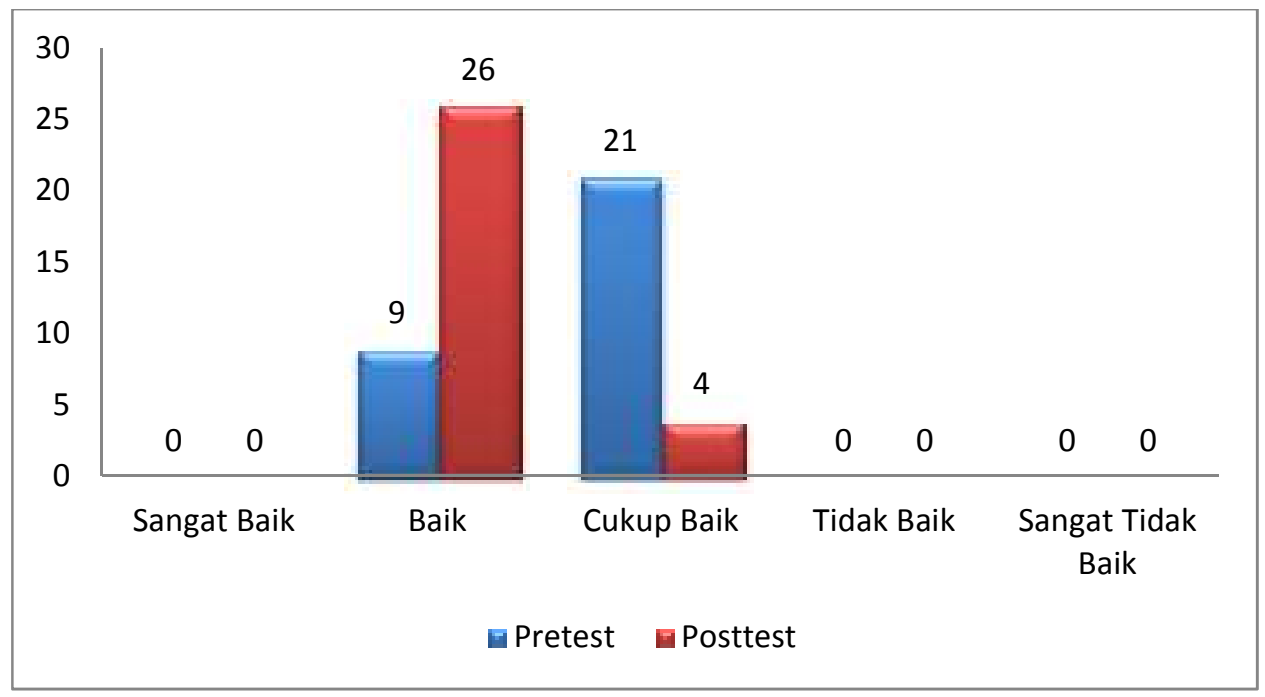

\section{Diagram 6 : Hasil Posttest Kontrol Diri Remaja Siswa SMK Melakukan Pelecehan Seksual Kelompok Eksperimen dan Kelompok Kontrol}

Berdasarkan diagram di atas, menunjukan terdapat perbedaan peningkatan kontrol diri remaja siswa SMK melakukan pelecehan seksual kelompok eksperimen yang sudah mengikuti layanan informasi dibandingkan dan kelompok kontrol yang mengikuti layanan informasi secara konvensional. Diagram di atas menunjukan layanan informasi lebih efektif dalam meningkatkan kontrol diri siswa melakukan pelecehan seksual.

\section{Pembahasan}

Berdasarkan hasil penelitian ditemukan terdapat perbedaan kontrol diri remaja siswa SMK melakukan pelecehan seksual setelah mengikuti layanan informasi. Pelecehan seksual dapat dibuktikan dalam tiga cara berbeda yaitu, verbal, fisik dan non-verbal. Pelecehan seksual terbagi atas dua, berhubungan langsung dan tidak berhubungan langsung dengan korban (Okoroafor, 2012; Firman, 2015). Pelaku pelecehan seksual tidak jarang orang terdekat korban. Seperti tetangga, kakak atau teman sekelas, pacar, bahkan saudara (MacLennan, 1993; Firman Firman, 2015). 
Perbedaan kontrol diri melakukan pelecehan seksual disebabkan karena keterbatasan informasi yang diperoleh remaja Siswa SMK.Kondisi tersebut menyebabkan keterampilan mengatasi masalah terbatas dibandingkan dengan orang dewasa. Keterampilan remaja siswa SMK mengatasi permasalahan seksual disebabkan oleh pendidikan seksualitas yang diterima tidak sesuai dengan realitas perilaku seksual dan resiko yang akan dihadapinya. Kondisi ini disebabkan oleh anggapan permasalahan seksualitas dipandang tabu diberikan di sekolah.Pendidikan selama ini cenderung menekankan kepada bahaya dan resiko seks pranikah yang dilihat dari moral dan agama (Pakasi \& Kartikawati, 2013).

Guru BK/Konselor Sekolah selama ini mengurusi dan membantu siswa yang bermasalah dengan kegiatan konseling secara multi disipliner (Creagh, 2004). Setelah diberikan layanan informasi dalam pelaksanaan bimbingan dan konseling di sekolah ditemukan terdapat perbedaan yang signifikan pemahaman siswa terhadap dampak seks bebas sebelum dan sesudah diberikan layanan informasi.Kondisi ini menunjukan layanan informasi dapat peningkatkan pemahaman dampak perilaku seks bebas di sekolah (Nurhalimah, 2013) .

Layanan informasi yang diberikan berupa pengendalian kognitif, tingkah laku dan pengambilan keputusan dapat meningkatkan kontrol diri remaja siswa SMK. Layanan informasi menggunakan pendekatan Contextual Teaching and Learning efektif dalam pencegahan pelecehan seksual remaja di Sekolah Menengah Atas (Firman Firman, 2015).

Di sisi lain, layanan informasi used CTL approach effective to the reduction of the student pornography tendencies. Counselors are recommended to apply the CTL approach on reducing it.(Asmidaryani et al., 2018). Materi yang dibahas melalui layanan informasi berperan dalam peningkatan kontrol diri remaja. Bahan bacaan yang digunakan selama pelaksanaan layanan informasi dapat memperkuat kontrol diri remaja siswa SMK. The results show that the service implementation guidelines are considered feasible and the level of dependability in the category is very high (Berliantika, Firman, Herman Nirwana, 2018)

Pemanfaatan layanan informasi bemanfaat dalam peningkatan kontrol diri. Siswa yang mengikuti layanan informasi ditemukan perbedaan kontrol dirinya sebelum dan sesudah mengikuti layanan informasi dengan metode problem solving (Romarta Fitri Yana, Firman, 2015).Dengan demikian pemanfaatan layanan informasi bermanfaat dalam peningkatan kontrol diri remaja siswa SMA melakukan pelecehan seksual.

\section{KESIMPULAN}

Berdasarkan hasil penelitian, dapat disimpulkan layanan informasi efektif dalam peningkatan kontrol diri remaja siswa SMK melakukan pelecehan seksual. Secara khusus, hasil penelitian dapat disimpulkan sebagai berikut:

1. Terdapat perbedaan kontrol diri melakukan pelecehan seksual remaja siswa SMK pada kelompok eksperimen sebelum dan sesudah mengikuti layanan informasi. 
2. Terdapat perbedaan kontrol diri remaja siswa SMK kelompok kontrol melakukan pelecehan seksual sebelum dengan sesudah mengikuti layanan informasi.

3. Terdapat perbedaan kontrol diri remaja siswa SMK melakukan pelecehan seksual kelompok eksperimen dibandingkan kelompok kontrol setelah mengikuti layanan informasi dilaksanakan.

Kepustakaan

Asmidaryani., firman., gistituati, n. (2018). The effectivenes of layanan informasi using contextual teaching and learning ( ctl ) approach to degree of students pornography trends, 133-144.

Syaiful Bahri \&Fajriati,.( 2015). Bahri, S. (2015). Pelecehan Seksual Di Aceh, 9, 50-65.

Berliantika,. Firman., Herman Nirwana., syahniar. (2018). Bibliotherapy to improve self-control in the prevention of sexual harassment. In univeristas negeri padang (pp. 1-6).

Collier, Rohan (1992) : Pelecehan SeksuaL : Hubungan Dominasi Mayoritas dan Minoritas. Yogyakarta : PT. Tiara Wacana.

Creagh, s. (2004). Pendidikan Seks di SMA D.I. Yogyakarta, (September), 1-79.

Firman., Syahniar,. (2015). Pencegahan pelecehan seksual remaja melalui layanan informasi menggunakan pendekatan contextual teaching and learning di sekolah menengah atas (sma). Researchgate.net,

Fuadi, M. A. 2011. Dinamika Psikologis Kekerasan Seksual: Sebuah studi fenomenologi. Malang:UIN Malang

Komisi Nasional Perempuan. 2016. Lembar Fakta Catatan Tahunan Komnas Perempuan. (online) Komnasperempuan.go.id diakses pada tanggal 27 Februari 2017.

Komisi Perlindungan Anak Indonesia. 2016. Tabulasi Data Kasus Anak. (online) KPAI.go.id. diakses pada tanggal 27 Februari 2016.

Kusmiran, E. 2012. Kesehatan Reproduksi Remaja dan Wanita. Jakarta: Salemba Medika.

MacLennan, B. W. (1993). Special issue: group treatment after child and adolescent sexual abuse: introduction. Jornal of Child and Adolescent Group Therapy, 3(1), 3-11.

Nurhalimah, s. (2013). Siti nurhalimah. Jurnal bk unesa, volume 04 , 14 4-1 53.

Okoroafor, N. C. (2012). Primary prevention knowledge of parents and teachers of nursery and play group on child sexual abuse. International Journal of Evaluation and Research in Education, 1(2), 73-78.

Pakasi, d. T., \& Kartikawati, r. (2013). Antara kebutuhan dan tabu: pendidikan seksualitas dan kesehatan reproduksi bagi remaja di sma. Jurnal makara seri kesehatan, 2(17), 79-81. Https://doi.org/10.7454/msk.v17i2.xxxx

Romarta fitri yana.,Firman., Yenikarneli,. (2015). Efektivitas layanan informasi dengan metode problem solving terhadap peningkatan kontrol diri siswa,. Jurnal Ilmiah Konseling, (2), 1-11. https://doi.org/10.31227/osf.io/rs6d7

Rumini, S. dan Siti, S (2004). Perkembangan Anak dan Renaja : Buku Pegangan Kuliah. Cetakan Pertama. Jakarta : PT. Rineka Cipta. Fakultas Ilmu Pendidikan. Universitas Yogyakarta. 
Yuniar, Dika dan Anggela .2013. Pola Asuh Otoriter, Kontrol Diri Dan Perilaku Seks Bebas Remaja SMK. Pesona, Jurnal Psikologi Indonesia, Mei 2013, Vol 2, No.2, Hal 173-182). 